\title{
ISLAMIC EDUCATION \\ IN A PLURALISTIC SOCIETY
}

\section{Agus Nuryatno}

Faculty of Tarbiyah, State Islamic University (UIN) Sunan Kalijaga, Yogyakarta, Indonesia

\section{Abstract}

The focus of this paper concerns how to construct an Islamic education that corresponds to a pluralistic society like Indonesia's. To answer this question it refers to a theory of religious education that consists of three models: in, at, and beyond the wall. Religious education in the wall is a model of religious education that's only concern is with its own religion, without connecting it with other religions. The second model is religious teaching at the wall, where students are not only tanght about their own religion but is also connected with other religions. The last model is religious education beyond the wall, which means helping students to work, together with people of other faiths for peace, justice, and harmony. From these models, the dominant practice of Islamic education is based on the first model, religious teaching in the wall. For this reason, I shall argue that it is necessary to shift the model of Islamic teaching from in to at and beyond the wall, in order for Muslim students to not ignorant of other religions and to make them able to work. together with other students of different faiths to combat the common enemy of religions such as violence, poverty, corruption, manipulation, and the like. To make Islamic teachers capable of implementing this model of religious teaching, it is necessary to have types of religiosity that correspond to it, namely inclusive-pluralist religiosity, critical-reflective religiosity, multicultural religiosity, bumanist religiosity, and social-active religiosity.

Pertanyaan inti yang hendak dijawab melalui artikel ini adalah bagaimana 
mengkonstruk pendidikan Islam yang sesuai dengan masyarakat plural seperti Indonesia. Untuk menjawab pertanyaan tersebut, penulis merujuk teori pendidikan agama yang terdiri dari tiga model: in, at, dan beyond the wall. Pendidikan agama in the wall adalah model pendidikan agama yang hanya memperhatikan agama sendiri tanpa mendialogkan dengan agama yang lain. Model kedua, pendidikan agama at the wall, tidak hanya mengajar siswa tentang agama mereka sendiri, tapi juga agama yang lain. Model terakbir adalah pendidikan agama beyond the wall, yang membantu siswa untuk bekerjasama dengan siswa lain meski berbeda agama demi tegaknya perdamaian, keadilan, dan harmoni. Dari ketiga model ini, praktek dominan pendidikan Islam didasarkan pada model pertama, yaitu pendidikan agama in the wall. Untuk itu penulis berargumen bahwa sudah saatnya untuk menggeser model pendidikan agama dari in ke at dan beyond the wall, agar siswa Muslim tabu dan kenal akan agama yang lain dan menjadikan mereka mampu bekerjasama dengan siswa lain yang memeluk agama berbeda dengan tujuan memerangi musuh utama agama, yaitu kekerasan, kemiskinan, korupsi, manipulasi, dan sejenisnya. Agar guru-guru agama Islam mampu menerapkan model pendidikan agama seperti ini, maka mereka perlu memiliki model-model keagamaan yang sesusai dengan spirit tersebut, seperti model keagamaan inklusif-pluralis, kritis-reflektif, multikultural, bumanis, dan aktif-sosial.]

Key words: pluralism, pluralistic society, religious education, multiculturalism

\section{A. Introduction}

Plurality of ethnicity, religion, and culture is a historical fact in Indonesian society. Plurality, diversity, and multiculturalism have two possible implications; positive or negative. They would enrich people's lives when their existence are admitted, tolerated, and respected. In contrast, plurality, diversity, and multiculturalism also produce negative impacts such as tension, conflict, and violence, when they are manipulated by certain groups for their own interest. Based on the Annual Report of Religious Life, there were 54 cases of religious-based violence in Indonesia during the year 2009. ${ }^{1}$ This shows that the challenges of

${ }^{1}$ CRCS-UGM, Annual Report of Religious Life (Yogyakarta: CRCS-UGM, 2010). 
pluralism and multiculturalism are not over yet.

Although conflict and violence are happening everywhere, inside and outside Indonesia, and producing a process of dehumanization ${ }^{2}$, they are only historical fact, but not "ontological vocation" of human beings. ${ }^{3}$ The ontological vocation of human beings is humanisation, a process of becoming authentic human beings, insān kämil (Ar.), or full human beings, ${ }^{4}$ who are tolerant and respectful of others. In the process of 'becoming', humans are called upon continually to humanize themselves through naming the world by active-reflective interaction with other humans. To use Colin Lankshear language, humans "are 'beings of the praxis' who live authentically only when engaged in inquiry and creative transformation of the world," "the world that is more humane, just, and egalitarian.

Education is a means for people to be more humane. At this point, education cannot be reduced to its meaning of only preparing pupils to get job in an industrial society, ${ }^{6}$ arguing that education is located in practical, pragmatic, and short term interests. There is no doubt, that today we are witnessing the expansion of a pragmatic culture within our society, and this culture is more and more influential in human life. Pragmatic culture is a product of capitalism and positivism. The influence of capitalism and positivism is clear: science that is disseminated to students is a science that orients them to adapt to industrial society. In the era of capitalism and positivism, corporate values serve as foundations of education at the expense of academic, just, and egalitarian values. ${ }^{7}$ The

2 Dehumanization is a concept popularized by Paulo Freire as "a distortion of the vocation of becoming more fully human". Paulo Freire, Pedagogy of the Oppressed (New York: Herder and Herder, 1971), p. 28.

3 "Ontological vocation" of human beings is a term used by Paulo Freire to describe a human beings' innate duty to realise his/her potential as a human.

${ }^{4}$ Paulo Freire, Pedagogy of the Oppressed (New York: Herder and Herder, 1971), p. 28.

5 Colin Lankshear, "Functional Literacy from a Point of View", in Peter McLaren dan Peter Leonard (ed.), Paulo Freire: A Critical Encounter (London and New York: Routledge, 1993), p. 95.

${ }^{6}$ M. Agus Nuryatno, Mą̧hab Pendidikan Kritis (Yogyakarta: Resist Book, 2008), pp. 82-3.

7 Barton, Angela Calabrese. (2001). Capitalism, Critical Pedagogy, and Urban Science Education: An Interview with Peter McLaren. In Journal of Research in Science 
meaning of education is far more than just this pragmatic perception. Education should be perceived as a means to humanize human beings, to prepare people living in and with the world, and to help them to become agents for themselves. ${ }^{8}$

The above perspective shows that there is no single interpretation of education. Education is always ambiguous and not neutral; it is always based on certain interests, ideology, and philosophy. ${ }^{9}$ Education is able to facilitate individuals who are pragmatic as well as idealist; as a means of productive as well as a reproductive forces; to maintain a hegemony or counter-hegemony; maintain a culture of silence or culture of criticism; strengthen or weaken the spirit of pluralism-multiculturalism; developing harmony or creating tension, conflict, violence, prejudice, and disharmony. ${ }^{10}$

Multiple interpretations and praxis of education can come into existence as people have different perceptions and interests toward education. Likewise, Islamic education can create two different kind of individuals; individuals who promote and respect plurality, diversity, and multiculturalism, or individuals who are intolerant and against plurality, diversity, and multiculturalism. At this point, Islamic education contributes to either maintaining or to threatening plurality, ethnic and religious diversity, and culture in Indonesia. The question is: How to construct an Islamic education that possibly contributes to strengthening pluralism and multiculturalism in Indonesia? How to promote a culture of tolerance in school education?

Before discussing further, it is better to clarify the meaning of Islamic education. The obvious meaning of Islamic education is the study of Islam. However, beneath this apparently simple answer lies a number of perplexities and a number of different points of view. It is useful to borrow Michael Grimmit's distinction of religious education as learning religion, learning about religion, and learning from religion, ${ }^{11}$ as a

\footnotetext{
Teaching, Vol. 38, No. 8, 847-59.

${ }^{8}$ Paulo Freire, Pedagogy of the Oppressed, p. 56.

9 Henry A. Giroux, Pedagogy and the Politics of Hope: Theory, Culture, and Schooling (Boulder, Colo.: Westview Press, 1997).

${ }^{10}$ M. Agus Nuryatno, Mą̧ hab Pendidikan Kritis (Yogyakarta: Resist Book, 2008).

11 Michael Grimmit, Religious education and buman development (Great Britain: Mc Crimmon, 1987), pp. 67-8.
} 
framework to define Islamic education. Religious education as learning religion means the transmission of religious culture, belief, and values from one generation to the next. The function of religious education in this perspective is to perpetuate and to hand on religious values and tradition. Religious education as learning about religion means studying religion in a purely objective and descriptive manner, not merely absorbing or receiving religious values. This approach can be called an objective form of teaching religion. The third distinction is learning from religion, which emphasises the advantages gained by individuals who study of religion. How religion could possibly contribute to illuminating human problems? What religious values are valuable for human life? These three distinctions of religious education can be applied in the study of Islam or particularly Islamic education. Following Grimmitt's distinction, the meaning Islamic education in this paper can be learning Islam, learning about Islam, and learning from Islam.

In order to have theological foundation of the relation between Islamic education and pluralism, it is necessary to see how Islam responds to the idea of pluralism.

\section{B. Islam and Pluralism}

Normatively, Islam has an extraordinary spirit for pluralism and multiculturalism. The Qur'an explicitly commands Muslims to appreciate and respect diversity and differences. "O mankind, surely We have created you from a male and a female, and made you tribes and families that you may know each other. Surely the noblest of you with Allah is the most dutiful of you. Surely Allah is Knowing, Aware."12 "And of His Signs is the creation of the heavens and the earth and the diversity of your tongues and colours. Indeed there are Signs in this for the wise."13

If we look at the above verses, it is clear that the plurality of ethnicity, religion, race, and nation had been sighted by Islam for centuries. Muslims should stick, uphold and be consistent with this principle. To use Asghar Ali Engineer's words, they are "normative verses," that are eternal and can be applied beyond time and space. The diversity and pluralism should be managed in such a way so that human dignity,

\footnotetext{
12 QS. al-Hujurāt, 49: 13.

13 QS. al-Rūm, 30: 22.
} 
regardless of their ethnicity, religion, race and nation, is respected and protected. Instead of a politics of assimilation, a politics of recognition should become the foundation of human life ${ }^{14}$, arguing that the latter is closer to the doctrine of Islam. "Believers, let not a group (of men) scoff at another group, it may well be that the latter (at whom they scoff) are better than they; nor let a group of women scoff at another group, it may well be that the latter are better than they. And do not taunt one another, nor revile one another by nicknames."15

Not only in the sphere of ethnic, racial, linguistic and cultural plurality does Islam accommodate and acknowledge variety, but also in the plurality of faith as well. "There is no compulsion in religion." "And say: "Truth derives from your God; so who wants to be a mukmin (believe in God) be a mukmin, and who wants to be a kafir (infidel), be a kafir." ${ }^{17}$ Thus, there is no compulsion in Islam. God has already declared him/ herself that he/she does not have any intention to make every human being become Muslim. If God gives human beings a freedom to choice, nobody has the authority and the power to force someone to follow a certain religion. Nobody is more powerful than God.

However, we have to acknowledge that some verses in the Qur'an textually and literally do not support pluralism. For example, those who do not associate with Allah in His Divinity are unclean, and they are not allowed to go near the Sacred Mosque; ${ }^{18}$ it is permitted to do violence or to take a tough action to those infidels and women; ${ }^{19}$ and Muslims are not allowed to take the unbelievers, the Jews, and Christians as their

14 Politics of assimilation and politics of recognition is part of theoretical cencept of multicultural education. Politics of assimilation refers to a process of assimilation of marginal or small groups to the dominant group of society. The philosophy behind this view is there must be a leading culture who run the society, and other cultures should follow that dominant culture. Meanwhile, politics of recognition argues that it is unnecessary for the marginal group of society to assimilate to the dominant group; and in contrast, diverse groups of society must be protected and recognized. There is an equal relationship between the dominant and the subordinant groups in society.

15 QS. al-Hujurāt, 49: 11.

16 QS. al-Baqarah, 2: 256.

17 QS. al-Baqarah, 2: 29.

18 QS. al-Tawbah, 9: 28.

19 QS. al-Fath, 48: 29; al-Nisā', 4: 34. 
allies because they are the allies of each other ${ }^{20}$ an order to fight against those who do not believe in Allah and the Last Day, and who do not follow the true religion, until they pay tribute out of their hand and are utterly subdued. ${ }^{21}$

If we look at the above verses, it seems that the Qur'an in a literal sense is contradictory from one verse over the other with some verses strongly supporting pluralism and multiculturalism, while the others state the opposite. On the other position, the Quran declares itself as a mercy for the whole universe. ${ }^{22}$ The question is: how to reconcile both of them? To answer this question I would like to refer to the work of Asghar Ali Engineer, an Indian Muslim thinker.

Asghar Ali Engineer proposes to reconcile the contradiction of verses in the Qur'an. ${ }^{23} \mathrm{He}$ argues that the Qur'an has two ingredients: normative and contextual. ${ }^{24}$ The distinction between normative and contextual elements is important for Engineer's understanding of the scripture. What he means by normative refers to the fundamental values and principles of the Qur'an such as equality, tolerant, and justice, and these principles are eternal and can be applied in various social contexts. Contextual revelations, on the other hand, deal with verses that were tailored to socio-historical problems of the time. In line with the changes in context and time, Engineer maintains, these verses can be abrogated. ${ }^{25}$ In Engineer's view, the normative feature is more akin to the divine,

20 QS. al-Nisā', 4: 144; al-Mā'idah, 5: 51.

21 QS. al-Tawbah, 9: 29.

22 QS. al-Anbiyā', 21: 107.

23 Asghar Ali Engineer, The Rights of Women in Islam (Lahore: Vanguard Books, 1992), p. 42; The Qur'an, Women and Modern Society (New Delhi: Sterling Publishers Private Limited, 1999), p. 52; M. Agus Nuryatno, “Asghar Ali Engineer's View on Liberation Theology and Women's Issues in Islam: An analysis," (Tesis: Institute of Islamic Studies, McGill University, Canada, 2000), pp. 54-6.

${ }^{24}$ Ibid., p. 42.

25 An example of this kind of abrogation is the case of slavery. In responding to this practice, which was common in Arabian society before Islam, the Qur'an does not abolish it immediately, because this was impossible. The Qur'an attempts to abolish it gradually, but until the end of revelation such custom still existed and was written in scripture. In line with change, today slavery is not permitted because it is against, not only universal values of the Scripture, but also against human rights. Asghar AIi Engineer, Justice, Women and Communal Harmony in Islam (New Delhi: Indian Council of Social Science Research, 1989). p. viii. 
while the contextual is more akin to the human. ${ }^{26} \mathrm{He}$ gives the example, seen from the normative perspective, the Qur'an favors equality between men and women ${ }^{27}$; it advocates gender equity. However, seen from the contextual perspective, the Qur'an frequently favors men a slight degree over women. ${ }^{28}$ The purpose of the distinction between normative and contextual is to highlight the difference between what is desired by Allah and that which is shaped by the empirical realities of society. Both are properties of the Qur'an, a text which is not only concerned with the ideal society as it "ought" to be, but also takes into account the empirical reality, or what "is". The dialectic between "ought" and "is" makes the scripture acceptable to people in the particular social context in which the verses were revealed, and also allows them to serve as blueprints for universal norms and principles that can be applied in the future conducive social reality. ${ }^{29}$ The distinction between these two characteristics can help promote tolerant, inclusive, and civic values. Engineer calls this approach "pragmatic-ideological course." 30

By employing the above method proposed by Engineer, I would argue that some verses that seem to not support the idea of pluralism and multiculturalism should be viewed as contextual verses that are shaped by the empirical realities of society, and consequently, the application of these verses are limited and conditional, not going beyond the time and space of their revelations. In contrast, some verses that support the idea of pluralism and multiculturalism could be located as normative verses, because they are basic principles for creating harmony for human beings.

${ }^{26}$ Asghar Ali Engineer, The Qur'an, Women and Modern Society (New Delhi: Sterling Publishers Private Limited, 1999), p. 52.

27 See, for instance, the Qur'an, chapter 33:35. The translation of this verse is as follows: "Men and women who have submitted, believed, obeyed, are truthful, steadfast, reverent, giving in charity, fasting, guarding their private parts and remembering Allah often, Allah has prepared for them forgiveness and a great reward."

${ }^{28}$ See, for instance, the Qur'an, chapter 4:34. The translation of this verse is as follows: "Men are in charge of women because Allah has made some of them excel the others, and because they spend some of their wealth. Hence righteous women are obedient, guarding the unseen which Allah has guarded. And those of them that you fear might rebel, admonish them and abandon them in the bed and beat them Should they obey you, do not seek a way of harming them; for Allah is Sublimeand Great!"

29 Engineer, The Rights of Women in Islam, pp. 10-1.

${ }^{30}$ Engineer, The Qur'an, Women and Modern Society, p. 87. 
The above method of exegesis in interpreting the Qur'an by differentiating the normative and contextual verses gives affirmation that Islam supports religious pluralism. Alwi Shihab gives some notes on religious pluralism. ${ }^{31}$ Firstly, religious pluralism does not only acknowledge plurality of religions, but is also actively involved in that plurality. In other words, one is not only demanded to acknowledge the existence and rights of people with different faith, but also participate in understanding the similarities and dissimilarities of religions. Secondly, religious pluralism should be distinguished from the idea of cosmopolitanism, where many religions live in one area but they never communicate and interact one over the other. The philosophical basis of cosmopolitanism is individualism. Thirdly, religious pluralism does not mean relativism, a notion that locates everything, including religion, as a relative truth.

Thus, a person is a pluralist when he/she not only acknowledges the existence and the rights of other religions but also is involved in understanding the similarities and dissimilarities to achieve harmony within plurality. Acknowledging the existence and rights of other religions is only enough to reduce fanaticism, but it does not go far enough in contributing to strengthening the existence of pluralism. To use Nurcholish Madjid language, it is only "negative goodness." According to him, pluralism should be understood as "genuine engagement of diversities within the bond of civility." 32

Meanwhile, Abd. Moqsith Ghazali clearly defends a strongly religious pluralism within Islam by presenting theological and historical arguments. He quotes one of mufassir that said al-din wahid wa'-shari'at mukbtalifah (religion is one, and the manifestation of religion is diverse)..$^{33}$ Thus, religious pluralism does not mean that all religions are the same, they are different. It will be clearer if we look at the work of Frithjof Schuon, as drawn on by Huston Smith, who differentiates between the esoteric and exoteric dimensions of religion. ${ }^{34}$

31 Alwi Shihab, Islam Inklusif: Menuju Sikap Terbuka dalam Beragama (Bandung: Mizan, 1997), pp. 41-2.

32 Budhy Munawar-Rahman, Islam Pluralis (Jakarta: Paramadina, 2001), p. 31.

33 Abd. Moqsith Ghazali, Argumen Pluralisme Agama: Membangun Toleransi Berbasis Al-Qur'an (Depok: KataKita, 2009), p. 394.

${ }^{34}$ Huston Smith, "Introduction", in Frithjof Schuon, The Transcendent Unity of Religions (Wheaton, Ill.: The Theosophical Publishing House, 1993), p. xii. 


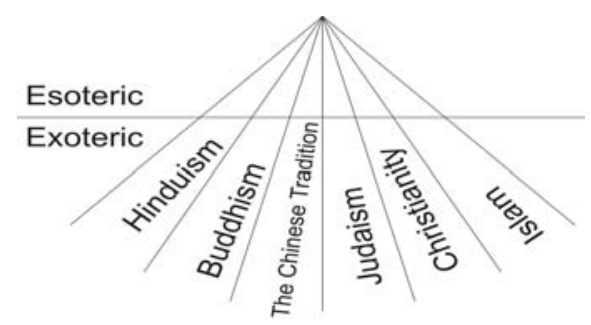

The above picture shows that the more one goes up the esoteric dimension, the more homogenous of religion will be, because it journeys towards God, although the God himself is called by numerous names. Frithjof Schuon calls this "the transcendent unity of religions." The argument of the transcendent unity of religion not only derives from the oneness of Truth, but the oneness of human beings as well. "The evidence for the transcendent unity of religions results not only from the oneness of Truth but also from the oneness of the human race." ${ }^{35}$

In contrast, the more one goes down the exoteric dimension the more diverse religion will be. This exoteric dimension is called syariat, or manifestations of religion that are diverse, differing from one tradition to the other. Thus, it is impossible to say that all religions are the same, because from this exoteric dimension all religions have their own manifestations.

The esoteric and exoteric dimensions of religion can be compared with the sunlight. The centre of the ray, that is The Truth, is only one, and not divided. From this Centre then radiates rays or "truths" like the sun that radiates its rays. The nature of the sunlight is only one, and this is the sun that illuminates the universe, from the past to the present. The nature of the light is only one, without colour, but people catch this light in different ways. "Although the nature of the true Religion is one, but because religions do not appear simultaneously in time and space, so that plurality and particularity form and language of religion cannot be avoided in the history." ${ }^{36}$ Esoteric dimensions of religion suggest that the ultimate goal of religions are the same, namely the God that has

35 Ibid., p. 149. To use Farid Esack, the peak dimension of esoteric is called tawhid, that is, "an undivided God for an undivided humanity"; Farid Esack, Qur'an, Liberation \& Pluralism (Oxford: Oneworld, 1997), p. 90.

${ }^{36}$ Komaruddin Hidayat dan Muhammad Wahyuni Nafis, Agama Masa Depan: Perspektif Filsafat Perennial (Jakarta: Gramedia Pustaka Utama, 2003), p. 45. 
multiple names. Not only from the esoteric dimension do religions have a common platform, but in the exoteric dimension as well. However, many religious adherents see only dissimilarities among religions.

\section{Shifting Model: From "in" to "at" and "beyond the wall"}

Given the fact that Indonesia is a pluralistic society, where there are a multitude of manifestations and expressions of different religions, we must ask what form of Islamic education would best correspond to this context? I shall argue that it is necessary to shift the paradigm of Islamic learning from in to at and beyond the wall. At this point, I employ the theory of teaching religion proposed by Jack Seymour ${ }^{37}$ and Tabitha Kartika Christiani. ${ }^{38}$ They propose three models of teaching religion, namely in, at, and beyond the wall. We are going to discuss these models in more detail.

Religious education in the wall means speaking the language used within the faith community. It is a phase of faith formation that only studies one's own tradition, without connecting it with other traditions. This model of religious education can possibly make students ignorant of other traditions, and because of this, misunderstanding and prejudice are very likely to occur. Not knowing other traditions could also produce distorted images of others and their faiths and raise a sense of superiority of one over the other. Religious education in the wall is parallel to that of an exclusive model of religious education, which produces a tough line of demarcation between "I" and "You", "We" and "They".

Religious education at the wall means using common terms to speak to the world or other faiths. This is a phase of faith transformation by learning and appreciating people of other faiths and conducting interreligious dialogue. Interreligious dialogue can be seen as a search for the maximum common denominator, or a broader sense of "common values." This model of religious education helps people to "see themselves as the others," and thus, reduce the sense of superiority of one over the other. The willingness to know the others would widen

${ }^{37}$ J.L. Symour (ed.), Mapping Christian Education: Approaches to Congregational Learning (Nashville: Abingdon Press, 1997).

${ }^{38}$ Tabita K. Christiani, "Christian Education for Peacebuilding in the Pluralistic Indonesian Context" in Religion, Civil Society and Conflict in Indonesia, Zurich: LIT VERLAG GmbH\&Co.KG Wien, 2009, pp. 173-91. 
perspectives and knowledge, avoid misunderstanding and prejudice, and develop a sense of respect and appreciation towards other religions. This can be employed as a religious modality to follow what Charles Kimball ${ }^{39}$ calls as "passing over and coming back," that is, temporarily leaving one's own tradition to enter another tradition and then returning back to his/ her own tradition. This concept helps students to enrich their own faith, appreciate the existence of other faiths, and recognise the particular and universal values of religions.

Religious education beyond the wall means helping students to work together with people of other faiths for peace, justice, and harmony. This is a phase of faith praxis. Teaching religion beyond the wall could possibly develop and strengthen solidarity of students of different faiths. Different faith is not a barrier to work together in the sake of humanity, because the prophetic mission of all religions is to make a better life for people in the earth. Religious education beyond the wall helps students to connect between theory, practice, knowledge and deed.

The above models of teaching religion proposed by Jack Seymour and Tabitha Kartika Christiani are relevant when applied to Islamic education. Models of teaching Islam in Indonesia are dominated by the in the wall model, that concentrates only teaching Islam per se, without connecting it with other religions. Consequently, many Muslim students are ignorant of other religions, and because of this ignorance, there are many prejudices and stereotypes towards people of different faiths, as if they are completely different from Islam and have no opportunity for salvation. ${ }^{40}$ This perception leads Muslim students to have a sense of superiority towards other people from different faiths.

For this reason, it is necessary to shift the model of teaching Islam, from teaching Islam in the wall to at and beyond the wall. Employing the model of teaching Islam at the wall would broaden perspectives and the knowledge of Muslim students towards other religions. Knowledge about other religions is an important precondition for the development of a culture of tolerance, and it helps to discover the shared values of religions. The exclusivity of certain religious or philosophical views and

39 Charles Kimball, Kala Agama Jadi Bencana (Bandung: Mizan, 2003).

40 There is a famous verse in the Qur'an that mentions salvation is only for those who belong to Islam. 
beliefs does not mean a negation of the principle of tolerance. Tolerance presupposes that you have a basic conviction that differs from the convictions of the person that you tolerate. However, there are meeting points between religions that can be shared, and these meeting points or values cannot come into existence without a willingness to know each other. Teaching religion in the wall would not be able to make these shared values come into existence. It is only through teaching religion at and beyond the wall that would possibly allow these universal values of religions to be discovered.

Moreover, teaching Islam at and beyond the wall contributes to reducing prejudices and stereotypes among Muslim students towards other people of different faiths. For example, in my class of multicultural education, ${ }^{41}$ there are questions regarding the tradition of Hinduism; one questioning the worship of statues and another questioning the caste system in Bali. In order to have an objective answer I called my Hindu friend, I Ketut Supena, to give some explanations in regard to these questions. He explained that actually Hindu's people do not worship to statue, but to God, what they call Sang Hyang Widi. Due to the abstract concept of God, they need mediums to get closer to God. Thus, statues are only mediums to worship Sang Hyang Widi. In regard to the caste system in Bali, Supena said that it is not true that Hindu's people are divided into Brahmana, Waysa, Ksatria, and Sudra, in a hierarchical way, where the upper is more respectable than the lower. There is no religion that acknowledges this kind of hierarchical position of human beings; all humans are equal. Supena argued that the categorization of Brahmana, Waysa, Ksatria, and Sudra has close meaning to professions instead of the hierarchical position of human beings. The profession of Brahmana deals with teaching Hindu religion, and when he finished doing his task, he goes back to daily work as worker, for instance, at which point his

${ }^{41}$ In this class I ask students to observe various social groups in society concerning their views on multiculturalism. I divided the class into seven groups and each group has task to observe one of the following groups: Catholic, Protestant, Hinduism, Buddhism, Confucius/Chinese, Mosque activists, and Ahmadiyah. Many of my students do not have any experience interact with other people of different faiths. This is the reason why I ask them to observe and interact with these groups in order to make them aware of other religious and social groups in society and to reduce prejudices of those groups. 
profession changes to Sudra. Thus, the categorization of Brahmana, Waysa, Ksatria, and Sudra is not static, but dynamic. Not all Hindu people may agree with this perspective, but at least it can reduce misconceptions and stereotypes among Muslim students toward the Hindu religion.

The last advantage of teaching Islam beyond the wall is that it gives Muslim students the opportunity to work together with other students of different faiths. For most Muslim students, may be this is a new experience, because many of them grow up in a system of "segregated education", or "homogenous education" in terms of religion where all students are Muslims. Working together among students of different faiths contributes to minimising prejudice, suspicions, and misunderstandings of one over the other. The theory of multiculturalism argues that learning about "the others" and intensifying contact of one group with another would minimize prejudice. Moreover, giving the opportunity for students of different faiths to work together would show them that the real enemy of religions is not among people of different faiths, but poverty, ignorance, violence, corruption, illegal logging, and the like. The prophetic mission of all religions is combating these problems, while at the same time, promoting justice, harmony, and peace. Teaching Islam thus, is not only a matter of how to transfer religious teachings, but more than that it is a process of transferring, internalising, and practicing religious knowledge. Teaching Islam does not only occur in the realm of theory or concept, but praxis as well. Islamic education should not only seek to propagate itself, but also to serve humanity. The mission of Islamic education is to enable young Muslim people and adults to be delivered from their own personal pain and to shoulder the pain of the world.

\section{Religiosity Types of Islamic Teachers}

To implement the model of Islamic education at and beyond the wall it is necessary for teachers of Islamic subject to have a type of religiosity that corresponds to the spirit of such model. There are several types of religiosity that possibly fit in implementing Islamic education at and beyond the wall, namely inclusive-pluralist religiosity, critical-reflective religiosity, multicultural religiosity, humanist religiosity, and social-active religiosity. ${ }^{42}$

${ }^{42}$ These types of religiosity I take from the work of Muhammad Ali, as quoted by M. Ainul Yaqin, Pendidikan Multikultural: Cross-Cultural Understanding untuk Demokerasi 
Inclusive-pluralist religiosity accepts the views that there are truths and goodness in other religions. Although the concept of God is different from one religion to another, their teachings are not completely different. There are meeting points of religious teachings such as justice, prosperity, truth, and humanity, and these should be located as "normative" teachings that can be applied to the past, present, and future. ${ }^{43}$ To acknowledge shared values of religions is not a taboo and not decreasing one's faith. Nor does it mean justifying that all religions are the same as propagated by those Islamists who oppose pluralism. Refuting the notion of shared values of religions is the same as refuting the teaching of Islam itself, because Islam is a continuity of other religions.

Multicultural religiosity is a type of religiosity that accepts plural expressions of religious practices such as tablilan, slametan, way of dressing, and the like. Teachers with multicultural perspectives would appreciate similarities and dissimilarities of social reality, whether based on religions or ethnicities. They would have the capacity to interact, negotiate, and communicate with people from diverse groups, because diversity is seen as socio-cultural enrichment, not as social boundaries. Based on the multicultural perspective, Islamic teachers would teach in tolerant and pluralistic way, by considering the plurality of the Islamic schools of thought of students. Teaching Islam in a monolithic way would not help Muslim students to learn about the diversity of manifestations of religiosity, whether in Islam or outside Islam, both inside and outside Indonesia. Under the multicultural perspective, Islam is also taught by considering the plurality of religions in Indonesia. Muslim students are called to respect the existence and rights of other religions, and even asks them to be involved in understanding the similarities and dissimilarities of the existed religions. The mission of this religious literacy is actually to prepare Muslim students to be a part of society, that is, a heterogeneous society in terms of social, culture, religion, ethnicity, and gender.

Humanist religiosity acknowledges the importance of humanistic values in practicing religion. Practicing religion cannot violate human rights, because Islam comes to the betterment of human life. At this dan Keadilan (Yogyakarta: Pilar Media, 2005), p. 56-7. However, I expand and give more detail explanation of these models.

${ }^{43}$ See the discussion of the differentiation of normative and contextual verses by Asghar Ali Engineer above. 
point, it is not enough for Islamic teachers to only "be religious" but also requires them to "be humanist" as well. There are Muslims who claim to be "religious persons", but in practice they carry out violence to others who have different views on Islam such as in the case of the Ahmadiyah and Shi'ah. Teachers with this type of religiosity would help avoid violence to solve religious or social problems, because violence is not part of their religious vocabulary. Instead of using violence they prefer to employ dialogical-persuasive way.

The next type of religiosity is social-active, which assumes that practicing religion is not merely a matter of fulfilling one's soul but also practiced through conducting practical things for humanity. Islamic teachers with this type of religiosity would always connect between religious teaching and deed. They are not common teachers, but "intellectual workers."

Critical-reflective religiosity holds the view that religious teachings should be accepted critically and reflectively, not taken for granted. Critical-reflective is necessary to understand, interpret, and practice religious teaching, because through it the essence of religion could be gained. Reading religion through a critical-reflective prism would make the implicit message of the teaching become explicit and religion would not be understood merely at the surface level, but its deep level. Islamic learning employing critical-reflective thinking would equip teachers and students with an intellectual capacity to distinguish between particularity and universality, and the symbol and essence of religions. This intellectual capacity would help them not to be trapped in blind religious fanaticism that always views religion from "black" and "white" angles, a similar perspective employed in physics or natural sciences.

Learning Islam critical-reflectively could be conducted through asking sensitive questions, such as: Is there any truth and goddess outside Islam? Is there salvation outside Islam? Does Allah send somebody to the hell only because he/she does not belong to Islam, although he/ she has very good deed in the world, like Mother Theresa, for example? Do you want to accept any help, material or non-material, from people of different faiths in establishing the mosque? Do you agree with some groups of Muslims who carry out violence towards the Ahmadiyah and Syiah groups? These critical questions train teachers and students to be 
used to dealing with sensitive issues, particularly issues with "the others". It is a process of opening ones mind and soul to know "the others" with reasons. Critical-reflective thinking helps teachers and students not to accept anything blindly, without reason. This process would allow them to avoid them acting without critical reasoning, or what is called by Freire "activism". ${ }^{44}$

Critical-reflective ways of learning religion cqn also be implemented through three steps: naming, reflecting, and acting. ${ }^{45}$ Naming is the step of questioning something: what is the problem? For example, the problem is about violence based on religion that happens in Indonesia. To deepen the understanding of the problem it is necessary to continue to the next step, reflecting, by asking such questions as: why is it happening? Why, for example, does a person voluntarily conduct a suicide bombing in the name of religion? What motivates such a person to do suicide bombing? Does religion justify someone to carry out a suicide bombing? This reflective process would help Muslim students to be critical and reflective, and avoid a simplistic analysis. In order to make processes of learning capable of giving solutions to the problem, it is necessary to continue to the next step, acting, by asking such questions as: what can be done to change the situation? This is to make the process of learning not stop at knowing and understanding the problem, but also to find the solution. Thus, teaching Islam is a combination of reflection and action or, not merely absorbing knowledge, but also taking action and making solutions. Employing this model to teach Islam means that Islamic education does not stop at the knowledge level but praxis as well.

Learning Islam through critical-reflective teaching is close to what Jack Mezirow calls "transformative learning", that is "the process by which we transform our taken-for-granted frames of reference (meaning perspectives, habits of mind, mind-sets) to make them more inclusive, discriminating, open, emotionally capable of change, and reflective so that they may generate beliefs and opinions that will prove more true or justified to guide action (italics mine)." 46 The core of

${ }^{44}$ Paulo Freire, Education as Cultural Action (New York: Herder and Herder, 1976).

${ }^{45}$ Paul V. Taylor, The texts of Paulo Freire (Philadelphia: Open University Press, 1993).

${ }^{46}$ Jack Mezirow, "Learning to Think Like an Adult: Core Concepts of Transformative Theory", in Jack Mezirow and Associate (eds.), Learning as Transformation: Critical Perspectives on a Theory in Progress (San Francisco: Jossey Bass, 2000), pp. 7-8. 
transformative learning is about changing the mind-set from merely a taken-for-granted standpoint in seeing text and reality, to one of being more reflective, critical, and open to change. When Islam is taught through transformative learning, it is possible to produce individuals who are reflective and open to change in reading, understanding, interpreting, and implementing Islamic teachings.

\section{E. Conclusion}

In a pluralistic society, like Indonesia, for instance, how should Islamic education be constructed? To answer this question it is necessary to look at the theory of religious teaching that consists of three models: teaching religion in, at, and beyond the wall. Religious teaching in the wall is a model of religious teaching that is only concerned with its own religion without connecting with other religion. The impact is that students are ignorant to other religions, and because of this ignorance there some prejudices and negative views towards different faiths, as if all religions are completely different. This model contributes to making a demarcation line between "I" and "You", "We" and "They". The second model is religious teaching at the wall, where students are not only taught about their own religion but also are connected with other religions. There has been religious dialogue in this model. The last model is religious education beyond the wall, which means helping students to work together with people of other faiths for peace, justice, and harmony. This is a phase of faith praxis. From these models, the dominant practice of Islamic education is on the first model, religious teaching in the wall. For this reason, I argue that it is necessary to shift the model of Islamic teaching from in to at and beyond the wall, in order to make Muslim students less ignorant of other religions and to make them better able to work together with other students of different faiths to combat the common enemy of religions such as violence, poverty, corruption, manipulation, and the like. For Islamic teachers able to implement this model of religious teaching, it is necessary to have a type of religiosity that correspond to it, namely inclusive-pluralist religiosity, critical-reflective religiosity, multicultural religiosity, humanist religiosity, and social-active religiosity 


\section{BIBLIOGRAPHY}

Barton, Angela Calabrese, "Capitalism, Critical Pedagogy, and Urban Science Education: An Interview with Peter McLaren", Journal of Research in Science Teaching, Vol. 38, No. 8, 2001.

Bowles, Samuel dan Herbert Gintis, Schooling in Capitalist America, New York: McMillan, 1976.

Engineer, Asghar Ali, The Rights of Women in Islam, Lahore: Vanguard Books, 1992.

----, The Qur'an, Women and Modern Society, New Delhi: Sterling Publishers Private Limited, 1999.

Esack, Farid, Qur'an, Liberation \& Pluralism, Oxford: Oneworld, 1997.

Freire, Paulo, Pedagogy of the Oppressed, New York: Herder and Herder, 1970.

Ghazali, Abd. Moqsith, Argumen Pluralisme Agama: Membangun Toleransi Berbasis Al-Qur'an, Depok: KataKita, 2009.

Giroux, Henry A., Theory and Resistance in Education: A Pedagogy for the Opposition, New York: Bergin \& Harvey Publishers, Inc., 1983.

----, Pedagogy and the Politics of Hope: Theory, Culture, and Schooling, Boulder, Colo.: Westview Press, 1997.

Hidayat, Komarudin, "Memetakan Kembali Struktur Keilmuan Islam (Kata Pengantar), in Fuaddudin dan Cik Hasan Basri, Dinamika Pemikiran Islam di Perguruan Tinggi: Wacana tentang Pendidikan Agama Islam, Jakarta: Logos, 1999.

----, Wabyu di Langit Wabyu di Bumi, Jakarta: Paramadina, 2003.

---- and Muhammad Wahyuni Nafis, Agama Masa Depan: Perspektif Filsafat Perennial, Jakarta: Gramedia Pustaka Utama, 2003.

Kimball, Charles, Kala Agama Jadi Bencana, Bandung: Mizan, 2003.

Kuhn, Thomas, The Structure of Scientific Revolutions, Chicago: University of Chicago Press, 1970.

Lankshear, Colin, "Functional Literacy from a Point of View", in Peter McLaren dan Peter Leonard (eds.), Paulo Freire: A Critical Encounter, London dan New York: Routledge, 1993. 
Mezirow, Jack, "Learning to Think Like an Adult: Core Concepts of Transformative Theory", in Jack Mezirow and Associate (eds.), Learning as Transformation: Critical Perspectives on a Theory in Progress, San Francisco: Jossey Bass, 2000.

Munawar-Rahman, Budhy, Islam Pluralis, Jakarta: Paramadina, 2001.

Naim, Ngainun \& Achmad Sauqi, Pendidikan Multikultural Konsep dan Aplikasi, Yogyakarta: Ar-Ruz Media, 2008.

Nuryatno, M. Agus, "Asghar Ali Engineer's View on Liberation Theology and Women's Issues in Islam: An analysis," Tesis: Institute of Islamic Studies, McGill University, Canada, 2000.

----, Mą̧ab Pendidikan Kritis, Yogyakarta: Resist Book, 2008.

Shihab, Alwi, Islam Inklusif; Membangun Sikap Terbuka dalam Beragama, Bandung: Mizan, 1997.

Smith, Huston, "Introduction," in Frithjof Schuon, The Transcendent Unity of Religions, Wheaton, Ill.: The Theosophical Publishing House, 1993.

Taylor, Paul V., The texts of Paulo Freire, Philadelphia: Open University Press, 1993.

Yaqin, M. Ainul, Pendidikan Multikultural: Cross-Cultural Understanding untuk Demokrasi dan Keadilan, Yogyakarta: Pilar Media, 2005. 